\title{
Management of Digestive Surgical Emergencies in Children in a Developing Country (Newborns Excluded)
}

Mboutol-Mandavo $\mathrm{C}^{1,2^{*}}$, Détsélé $\mathrm{RC}^{2}$, Miéret $\mathrm{JC}^{2}$, Akobande $\mathrm{NE}^{2}$, Ondima IPL ${ }^{1,2}$, Odzébé AWS ${ }^{1,3}$

${ }^{1}$ Faculty of Health Sciences, Marien Ngouabi University, Brazzaville

${ }^{2}$ Department of Pediatric Surgery, University Hospital of Brazzaville

${ }^{3}$ Department of Urology-Andrology, University Hospital of Brazzaville

Corresponding Author: Caryne Mboutol-Mandavo

Address: Pediatric Surgery University Hospital of Brazzaville. 13, Boulevard Auxence Ickonga PO Box: 32 Brazzaville; Tel: +242055456601; E-mail: carymbout@gmail.com

Received date: 28 December 2019; Accepted date: 10 February 2020; Published date: 18 February 2020

Citation: Mboutol-Mandavo C, Détsélé RC, Miéret JC, Akobande NE, Ondima IPL, Odzébé AWS. Management of Digestive Surgical Emergencies in Children in a Developing Country (Newborns Excluded). Asp J Pediatrics Child Health. 2020 Feb 18;2(1):19-29.

Copyright (C) 2020 Mboutol-Mandavo C, Détsélé RC, Miéret JC, Akobande NE, Ondima IPL, Odzébé AWS. This is an open-access article distributed under the Creative Commons Attribution License, which permits unrestricted use, distribution, and reproduction in any medium provided the original work is properly cited.

\section{Abstract}

Aim: It was a question of determining the epidemiological, diagnostic and therapeutic aspects of the digestive surgical emergencies of the child in our environment.

Patients and Methods: This is a prospective and descriptive study carried out for 12 months in the pediatric surgery department.

Results: During the study period, on 668 patients admitted we retained 87 cases of digestive surgical emergencies; representing a hospital frequency of $13 \%$. The mean age was $7.6 \pm 3.5$ years (range 30 days and 16 years). We noted a male predominance with 61 boys (70.1\%) for 26 girls (29.9\%). The taxi was the most used form of transportation in 77 cases (88.5\%). The average consultation time was 5.4 days \pm 5.3 days ( 1 hour and 21-day extremes). Abdominal pain was the main reason for consultation with $66.7 \%$ of cases. Generalized acute peritonitis was the predominant diagnosis with 32 cases $(39.1 \%)$, followed by strangulated parietal hernias with 17 cases (19.5\%) and acute intestinal intussusception with 11 cases (12.6\%). The postoperative course was complicated in 27 cases (33.7\%). parietal suppurations were the most common complication with $77.8 \%$ of cases. Six patients $(6.9 \%)$ died.

Conclusion: Digestive surgical emergencies represent a frequent nosological entity in our practice. Abdominal pain is the first reason for consultation. Appendicular peritonitis are the first cause of digestive surgical emergency in children in our practice. They remain a worrying problem for pediatric surgeons.

\section{Keywords}

Surgical Emergencies; Abdomen; Appendicitis; Peritonitis; Child

\section{Introduction}

Surgical emergencies of children remain one of the major concerns of pediatric surgeons and anesthetists [1]. Digestive surgical emergencies represent a vast pathological entity. It affects a large part of the population through the diversity of its symptoms and etiologies; because it cans be of infectious, congenital, traumatic causes, and vary from one region of the 
Citation: Mboutol-Mandavo C, Détsélé RC, Miéret JC, Akobande NE, Ondima IPL, Odzébé AWS. Management of Digestive Surgical Emergencies in Children in a Developing Country (Newborns Excluded). Asp J Pediatrics Child Health. 2020 Feb 18;2(1):19-29.

\section{Original Article}

world to another and according to the age of the child [2]. However in developing countries in general, and sub-Saharan Africa in particular, these conditions are characterized by high morbidity and mortality due to the significant difficulties in diagnostic and therapeutic management; this being linked to several factors including the precarious clinical condition of patients at admission, the low level of equipment in hospitals, the absence of pediatric anesthesiologist $[3,4]$.

We conducted this study to determine the epidemiological, diagnostic, therapeutic and progressive aspects of surgical emergencies in children in our practice.

\section{Patients and Methods}

It was a prospective, descriptive study, carried out from September 1, 2018, to August 31, 2019 (12month). It concerned children aged 1 month to 16 years admitted for a digestive surgical emergency, operated or not. We excluded newborns due to the specificity of neonatal digestive emergencies. During the study period, on 668 patients admitted, we retained 87 cases of surgical digestive emergencies; either a frequency of $13 \%$. The mean age was $7.6 \pm 3.5$ years (extremes 29 days and 16 years). We noted a male predominance with 61 boys $(70.1 \%)$ for 26 girls (29.9\%), either sex ratio of 2.3 .
We analyzed:

- The diagnostic aspects, the general condition at admission evaluated according to the Lansky scale [5] for infants and children or WHO [6] for adolescents, exit diagnoses.

- The therapeutic aspects: the surgical procedures performed, the duration of hospitalization, the results observed during hospitalization.

- The concept of death, the cause of death.

\section{Results}

Diagnostic Aspects:

The taxi was the most used form of transportation in 77 cases $(88.5 \%)$, followed by ambulance in six cases $(6.9 \%)$ and a private vehicle in four cases (4.6\%).

The average consultation period was 5.4 days \pm 5.3 days (extremes 1 hour and 21 days). The majority of patients had consulted after the first 72 hours $(51.7 \%)$ and $48.3 \%$ within the first 72 hours after the onset of symptoms. Abdominal pain was the main reason for consultation with $66.7 \%$ of cases (Table-1).

Thirty patients (33.9\%) were admitted in good general condition and $54(62.1 \%)$ had a moderate to severe deterioration in the general condition.

Hemodynamic state on admission, the hemodynamic state was stable in 69 patients $(79.3 \%)$

\begin{tabular}{|l|c|c|}
\hline \multicolumn{2}{|c|}{ Table-1: Distribution of Patients According to the Reasons for Consultation } \\
\hline \multicolumn{1}{|c|}{ Reasons of consultation } & $\mathbf{n = 8 7}$ & \% \\
\hline Abdominal pain & 58 & 66.7 \\
\hline Vomiting & 56 & 64.4 \\
\hline Hyperthermia & 36 & 41.3 \\
\hline Absence of stool and gas & 27 & 31 \\
\hline Constant crying & 24 & 27.6 \\
\hline Rectorrhagia & 13 & 14.9 \\
\hline Abdominal bloating & 10 & 11.5 \\
\hline Inguino scrotal pain & 2 & 2.3 \\
\hline Abdominal wound & 2 & 2.3 \\
\hline Food refusal & 2 & 2.3 \\
\hline Others & 3 & 3.3 \\
\hline
\end{tabular}


Citation: Mboutol-Mandavo C, Détsélé RC, Miéret JC, Akobande NE, Ondima IPL, Odzébé AWS. Management of Digestive Surgical Emergencies in Children in a Developing Country (Newborns Excluded). Asp J Pediatrics Child Health. 2020 Feb 18;2(1):19-29.

\section{Original Article}

and unstable in $(20.7 \%)$.

Abdominal defense was the physical sign most often-found $(79 \cdot 3 \%)$ on inspection (Table-2). Fifty- nine patients $(67.8 \%)$ had performed standard abdominal X-ray. it showed a diffuse greyness in 19 cases $(32.2 \%)$, aerocoly in 15 cases $(25.4 \%)$, and levels hydro-aeronautics in 36 cases (41.4\%).

\begin{tabular}{|l|l|l|}
\hline \multicolumn{2}{|c|}{ Table-2: Distribution of Patients According to the Main Physical Signs } \\
\hline \multicolumn{1}{|c|}{ Physical signs } & \multicolumn{1}{|c|}{$\mathbf{n = 8 7}$} & \\
\hline Defense / Abdominal Contracture & 69 & 79.3 \\
\hline Abdominal bloating & 61 & 70.1 \\
\hline Inguinal / scrotal swelling & 15 & 17.2 \\
\hline Umbilical swelling & 2 & 2.3 \\
\hline Abdominal wound & 2 & 2.3 \\
\hline Anal wound & 1 & 1.1 \\
\hline mass of intussusception & 1 & 1.1 \\
\hline
\end{tabular}

Forty-one patients (47.1\%) had performed an abdominal ultrasound; it showed an inflammatory appendix in 39\% of cases (Table-3). Ultrasound was contributory to the diagnosis in 32 cases $(78 \%)$ and non-contributory in nine cases (22\%).

Six patients (6.9\%) had performed a chest X-ray, five of which were normal and one had objectified left pleurisy.

No patient had performed an emergency CT or abdominal magnetic resonance imaging.

Generalized acute peritonitis was the predominant

\begin{tabular}{|l|c|c|}
\hline \multicolumn{2}{|c|}{ Table-3: Distribution of Patients According to Ultrasound Results } \\
\hline \multicolumn{1}{|c|}{ Ultrasound results } & $\mathbf{n = 4 1}$ & \% \\
\hline Inflammatory appendix & 16 & 39.0 \\
\hline Intra peritoneal collections & 15 & 36.6 \\
\hline Bowel distention & 8 & 19.5 \\
\hline Boudin d'invagination & 6 & 14.6 \\
\hline Intra-appendicular stercolith & 6 & 14.6 \\
\hline Haemoperitoneum & 3 & 7.3 \\
\hline Pre vesical abscess & 1 & 2.4 \\
\hline Absence of peristalsis & 1 & 2.4 \\
\hline Soft tissue infiltration & 1 & 2.4 \\
\hline
\end{tabular}

diagnosis with $39.1 \%$ of cases (Table-4).

\section{1) Generalized Acute Peritonitis}

On the 34 cases of generalized acute peritonitis, the acute appendicitis with 32 cases (93.5\%) was the most common etiology. The other etiologies were a case of post-cesarean endometritis and a case of traumatic perforation of the rectum.
2) Strangled Parietal Hernias

The inguinoscrotal hernia was the most common with 15 cases and umbilical hernia with two cases. Sixteen patients were operated on, 12 of whom had a viable intestinal loop and four cases of intestinal necrosis with two cases of pyostercoral phlegmon.

3) Acute Intestinal Invagination

On 11 cases of acute intestinal intussusception, nine 
Citation: Mboutol-Mandavo C, Détsélé RC, Miéret JC, Akobande NE, Ondima IPL, Odzébé AWS. Management of Digestive Surgical Emergencies in Children in a Developing Country (Newborns Excluded). Asp J Pediatrics Child Health. 2020 Feb 18;2(1):19-29.

\section{Original Article}

\begin{tabular}{|l|c|c|}
\hline \multicolumn{2}{|c|}{ Table-4: Distribution of Patients by Diagnosis } \\
\hline \multicolumn{1}{|c|}{ Diagnosis } & N & \% \\
\hline Generalized acute peritonitis & 34 & 19.5 \\
\hline strangulated hernia & 17 & 13.8 \\
\hline Acute appendicitis & 12 & 12.6 \\
\hline Acute intussusception & 11 & 5.7 \\
\hline Abdominal trauma & 5 & 3.4 \\
\hline Small bowel volvulus & 3 & 2.3 \\
\hline Mesenteric lymphadenitis & 2 & 1.2 \\
\hline Pre-bladder abscess & 1 & 1.2 \\
\hline postoperative bridle occlusion & 1 & 1.2 \\
\hline Enterocolitis / Hirschsprung disease & 1 & $\mathbf{1 0 0}$ \\
\hline Total & $\mathbf{8 7}$ & \\
\hline
\end{tabular}

patients had been operated on, one case of spontaneous reduction, 1 case of death. It was in all cases of idiopathic intussusception; the ileo-caecalcolic form was the most represented with six cases, ileo-ileal in 2 cases, and ileo-caeco-colo-rectal in one case.

\section{Therapeutic Aspects:}

Among the 87 patients who presented with a digestive surgical emergency:

- $\quad$ Eighty patients (91.9\%) were operated on.
- $\quad$ Four (4.6\%) had received medical treatment with a favorable development. These were 3 cases of abdominal contusion and 1 case of intussusception resolved spontaneously.

The majority of patients (86.3\%) were operated on after the 12th hour. The causes of delay in treatment are illustrated in (Fig-1). Surgical gestures performed (Fig-2). The average length hospitalization was 9.8 days with extremes of 1 and 35 days.

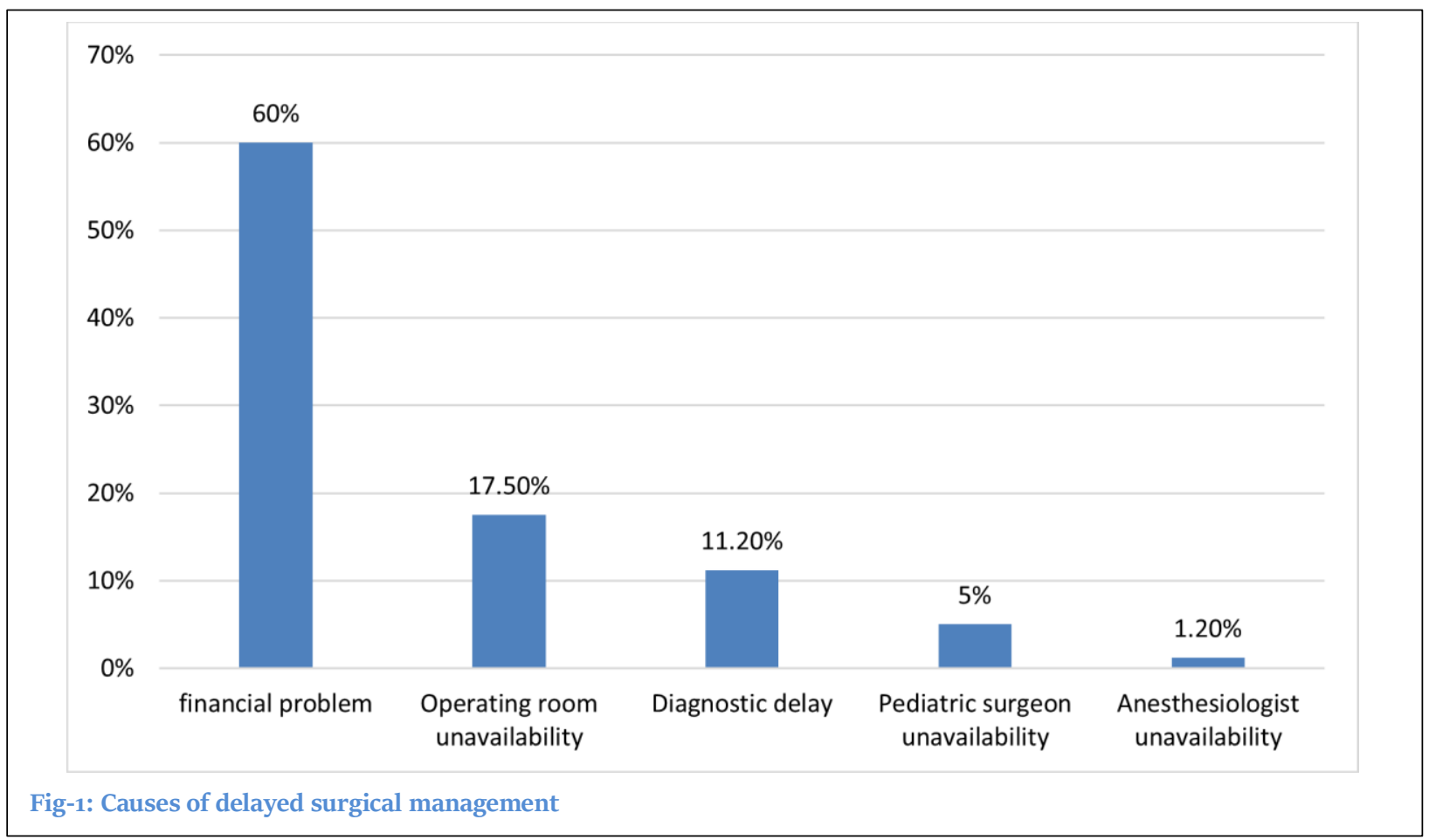


Citation: Mboutol-Mandavo C, Détsélé RC, Miéret JC, Akobande NE, Ondima IPL, Odzébé AWS. Management of Digestive Surgical Emergencies in Children in a Developing Country (Newborns Excluded). Asp J Pediatrics Child Health. 2020 Feb 18;2(1):19-29.

\section{Original Article}

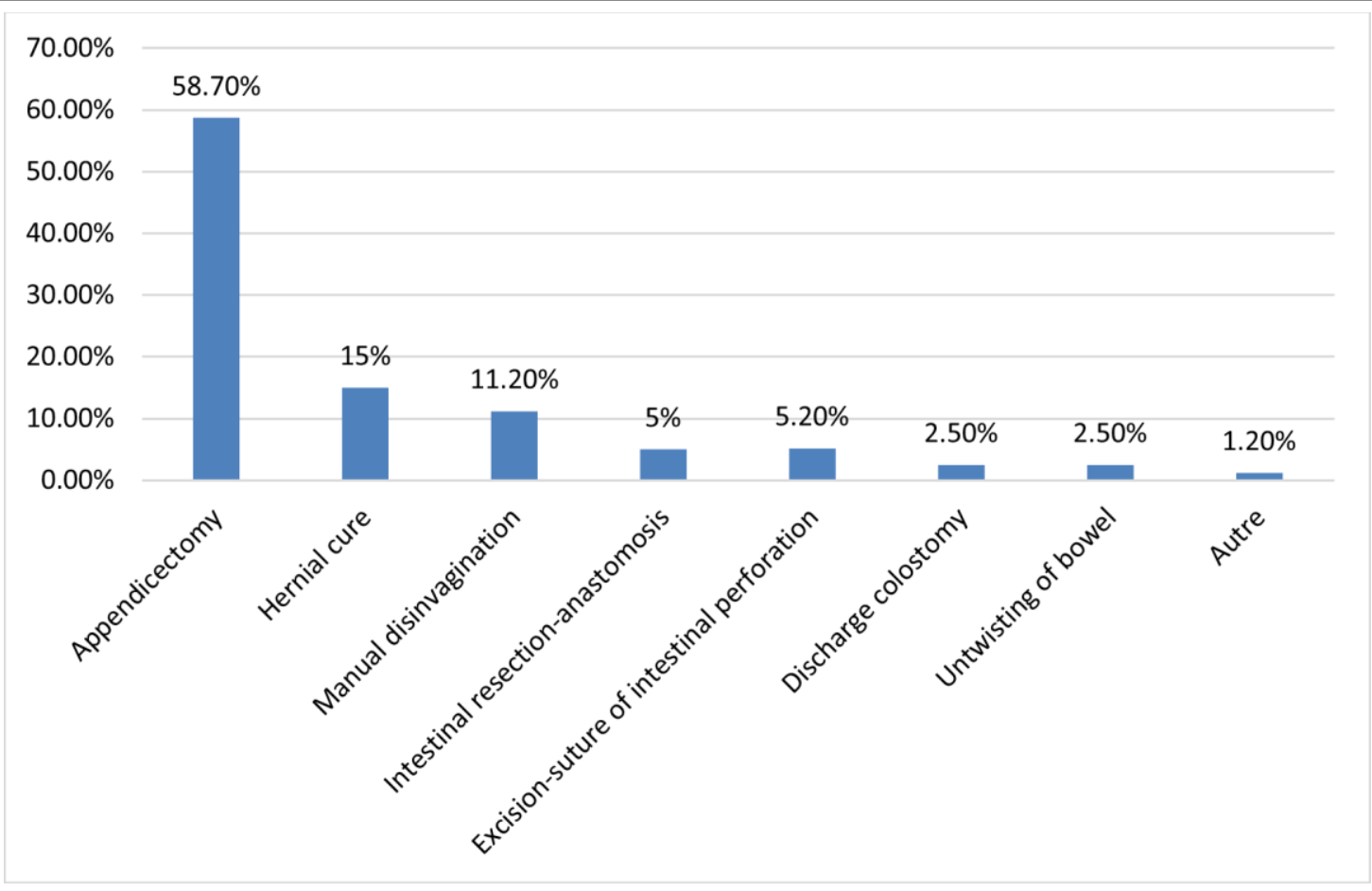

Fig-2: Distribution of patients according to surgical procedures

\section{Aspects Evolutionary:}

There were three cases of iatrogenic intestinal perforations intraoperatively. The postoperative evolution was simple in 53 cases (66.3\%) and complicated in 27 cases (33.7\%). The complications observed postoperatively are on (Fig-3). Of the 27 patients who presented postoperative complications, 6 $\mathbf{2} 2.2 \%)$ were operated again.

We did not observed any complications in patients operated on within 12 hours of admission. These complications occurred mainly in patients admitted

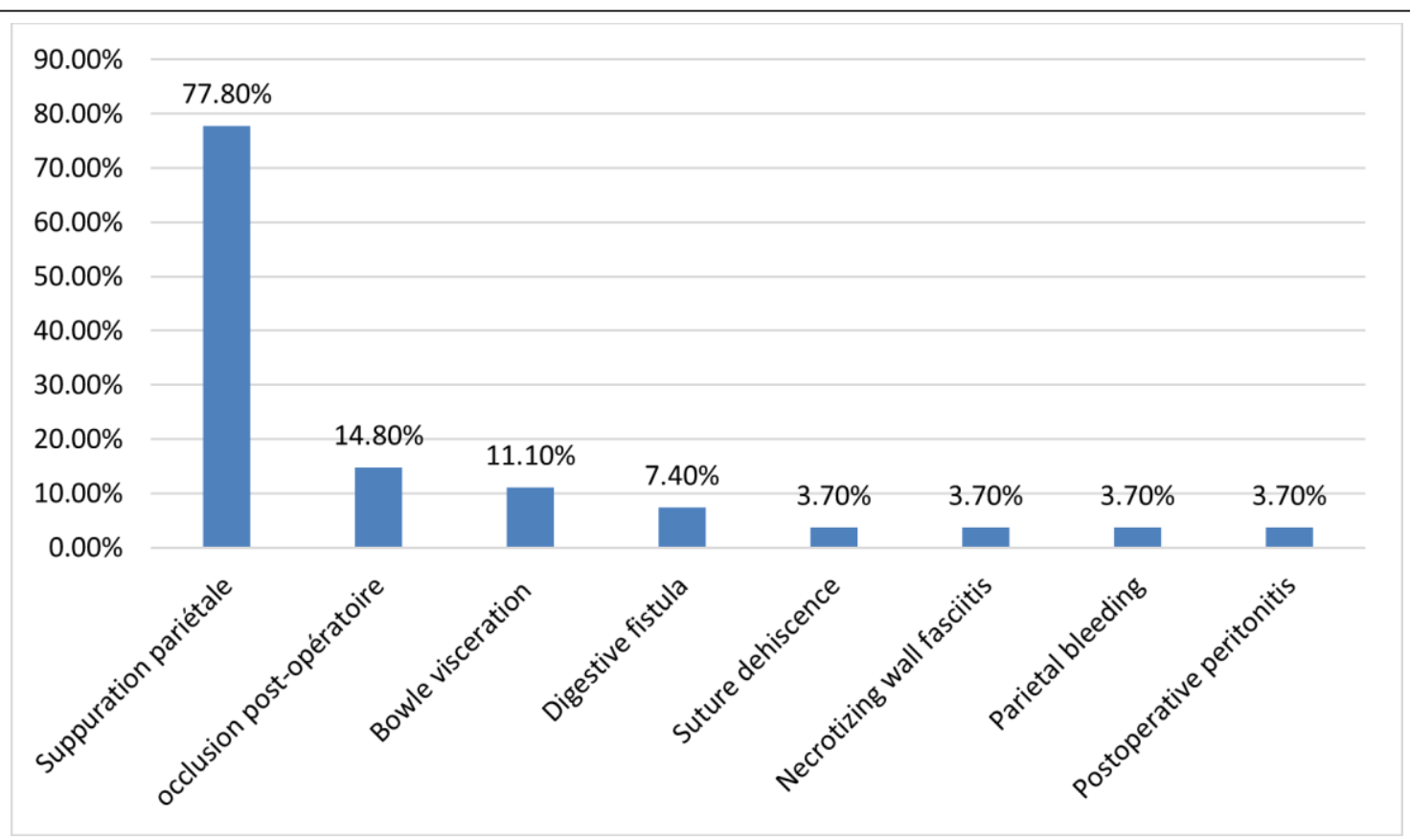

Fig-3: Postoperative complications 
Citation: Mboutol-Mandavo C, Détsélé RC, Miéret JC, Akobande NE, Ondima IPL, Odzébé AWS. Management of Digestive Surgical Emergencies in Children in a Developing Country (Newborns Excluded). Asp J Pediatrics Child Health. 2020 Feb 18;2(1):19-29.

\section{Original Article}

for peritonitis in 16 out of 34 cases, or $47.1 \%$.

Six patients $(6.9 \%)$ died: 1 ) three preoperatively: respectively one case of peritonitis, intussusception and strangled umbilical hernia. 2) Three postoperatively.

The age group from 1 month to 5 years was the most concerned with four cases against two cases concerning the age group 11-16 years. Septic shock was the leading cause of death, followed by multiple organ failure and hypovolemic shock.

\section{Discussion}

The frequency of gastrointestinal surgical emergencies in our series is close to those reported by other authors $[3,7,8]$ as well as the male predominance in the near middle age (Table-5).

\begin{tabular}{|l|c|c|c|}
\hline \multicolumn{3}{|c|}{ Table-5: Epidemiological Aspects of Patients According to the Authors } \\
\hline \multicolumn{1}{|c|}{ Studies } & Fréquency & Male gender & Average age \\
\hline Our study & $13 \%$ & $70.10 \%$ & $7.6 \mathrm{ans}$ \\
\hline Habou et al. [10] & $10.30 \%$ & $66.10 \%$ & $7.8 \mathrm{ans}$ \\
\hline Tseng et al.[9] & $10 \%$ & $67.50 \%$ & $10.6 \mathrm{ans}$ \\
\hline Mabiala et al.[4] & $14.10 \%$ & $67 \%$ & $8.3 \mathrm{ans}$ \\
\hline
\end{tabular}

Diagnostic Aspects:

1) The Mode of Transport

The taxi was the most used form of transportation (88.5\%). This low rate of medical transport is due to the low level of equipment of our health structures, in particular, the ambulance deficit and the absence of medical aid service in case of emergency in most of the countries of Sub-Saharan Africa. This lack of organized pre-hospital emergency medical care, as pointed out by other authors [9], is at the origin of the worsening of the morbidity and mortality of our patients.

The time for admission to our study was relatively long, as several African studies have already reported $[4,10]$; and it constitutes a factor of bad prognosis [11] linked to:

- The ineffectiveness of health systems in referring patients from poorly equipped centers to the university hospital;

- Socio-cultural reasons (traditional treatment, illiteracy, self-medication) and economic reasons (pecuniary problems, lack of health insurance). Half of the Congolese households live below the poverty line [12]; hospital costs represent an economic burden that is difficult to insure. This not only helps to lengthen the time it takes to go to hospital but also to increase the delay in getting treatment in hospitals.

Pain was the main reason for admission of our patients $(66.7 \%$ of abdominal seat, $2.3 \%$ inguinoscrotal) for children of speaking age; it should also be noted that for the youngest, incessant $(27.4 \%$ in our series) or paroxysmal crying, or even refusal to eat (2.3\%) are other modes of expression of pain [13]. This symptom is almost constant in the digestive surgical emergencies of the child. In the United States, it represents 5 to $10 \%$ of the reasons for consultation in pediatric emergencies [14]. Although most ER admissions that constitute acute abdominal injury are mild medical diagnoses, up to $20 \%$ of the surgical etiology may be present [14].

\section{2) General Signs}

At admission, more than half of the patients (62.1\%) had moderate to severe impairment of the general condition and $20.7 \%$ had an unstable hemodynamic condition. The precariousness of the clinical condition of patients on admission is related to the delay in consultation, and this contributes to increasing the morbidity and mortality of patients as already pointed out by most of the authors in the literature $[3,8]$.

Defense and abdominal contracture were the major 
Citation: Mboutol-Mandavo C, Détsélé RC, Miéret JC, Akobande NE, Ondima IPL, Odzébé AWS. Management of Digestive Surgical Emergencies in Children in a Developing Country (Newborns Excluded). Asp J Pediatrics Child Health. 2020 Feb 18;2(1):19-29.

\section{Original Article}

physical signs mentioned by all the authors; our rate of $79.3 \%$ is similar to that of the other series $[3,8]$. However, symptoms such as vomiting, diarrhea, abdominal pain, and fever are common and nonspecific in children, which can delay or disregard a surgical emergency [15].

\section{3) Imagery}

Standard Abdominal X-ray:

It is important for the diagnosis of many pathologies reaching or resounding on the abdomen and its contents. Rothrock et al. [16], by reducing the indications of the standard radiography of the abdomen the following clinical signs: history of abdominal surgery, ingestion of foreign body, abnormal digestive sounds, abdominal distension, and peritoneal signs, have shown that a $38 \%$ reduction in these requests in the pediatric environment was achievable with a negative predictive value of $99 \%$.

\section{Abdominal Ultrasound:}

It contributed to the diagnosis in $78 \%$ of the cases. Kouame et al. [17] found a positive predictive value of radiological results of $85.7 \%$. If all the authors of recent review articles published in radiological journals, [18,19] agree on the primordial importance of ultrasound in the management of pediatric abdominal emergencies, few articles quantify this benefit by a report on clinical examination. Van den Ende et al. [20] report a gain of almost $20 \%$ in positive predictive value from the combination of ultrasound and clinical examination (88\%) vs clinical examination alone (69\%). Carrico et al. [21] raise the stakes by up to $50 \%$ change in initial clinical diagnoses and 33\% increased diagnostic confidence after ultrasound in a population of children and young adults with acute abdominal and pelvic pain. These flattering figures for ultrasound should not mask that in daily practice, the age of the child and the clinicalbiological picture are crucial elements of orientation and most often allow the clinician to make the correct diagnosis without use an etiological imaging assessment.

In our series, no patient performed an emergency $\mathrm{CT}$ or abdominal magnetic resonance imaging. Due to the unavailability and high cost of these exams, ultrasound and an abdominal scan without preparation remain the only methods of exploring acute abdominal pain in children in sub-Saharan Africa.

However, abdominal computed tomography has an undeniable place in the positive, etiological diagnosis of abdominal emergencies. Its role in the management of appendicular syndrome has made significant progress in pediatric practice in a few teams, mainly in the United States [22]. Apart from the diagnostic impact of the ultrasound already mentioned, the risks and technical constraints (irradiation, iodine contrast injection, digestive markings, agitation of the child), are all parameters explaining the current lack of enthusiasm of Europeans for this type of imagery [23].

Pediatric indications for abdominal magnetic resonance imaging have also evolved. In the emergency context, this type of imagery remains second-line after the ultrasound.

However, each radiology department, pediatric or not, receiving pediatric emergencies will, of course, depending on its human resources and equipment, adapt its exploration strategy: a good ultrasound is better than a bad indication of irradiation.

\section{Diagnostics:}

(Table-6) represents the main causes of surgical emergencies according to the authors.

\section{4) Generalized Acute Peritonitis}

In our study, acute peritonitis is the primary etiology of SED in children (39.1\%), corroborating with the study by Habou et al. [8] in Niger. However, there is a discrepancy with the results of the studies by Tseng and al. [7] in Asia, whose primary diagnosis was acute appendicitis. This difference could be explained by the time for admission was relatively long (5.4 days \pm 5.3 days), contributing to a delay in treatment and therefore to the development of appendicitis towards complicated forms in particular peritonitis, as observed in developing countries [24]. 
Citation: Mboutol-Mandavo C, Détsélé RC, Miéret JC, Akobande NE, Ondima IPL, Odzébé AWS. Management of Digestive Surgical Emergencies in Children in a Developing Country (Newborns Excluded). Asp J Pediatrics Child Health. 2020 Feb 18;2(1):19-29.

\begin{tabular}{|c|c|c|c|c|c|}
\hline \multicolumn{6}{|c|}{ Table-6: Distribution of the First Three Etiologies According to the Authors } \\
\hline Authors & $\begin{array}{l}\text { Mabiala et al. } \\
\text { [4] N=185 }\end{array}$ & $\begin{array}{l}\text { Habou et al. } \\
{[10] \mathrm{N}=\mathbf{2 8 3}}\end{array}$ & $\begin{array}{l}\text { Tseng et al. [9] } \\
\qquad \mathrm{N}=400\end{array}$ & $\begin{array}{l}\text { Kouamé et al. [21] } \\
\qquad \mathrm{N}=93\end{array}$ & Our study $\mathbf{N}=87$ \\
\hline \multirow{3}{*}{ Pathologies } & $\begin{array}{l}\text { Acute appendicitis } \\
30.3 \%\end{array}$ & $\begin{array}{l}\text { Generalized } \\
\text { acute peritonitis } \\
61.8 \%\end{array}$ & $\begin{array}{l}\text { Acute appendicitis } \\
64 \%\end{array}$ & $\begin{array}{l}\text { Acute appendicitis } \\
32.2 \%\end{array}$ & $\begin{array}{l}\text { Generalized acute } \\
\text { peritonitis } 39.1 \%\end{array}$ \\
\hline & $\begin{array}{l}\text { Generalized acute } \\
\text { peritonitis } 28.1 \%\end{array}$ & $\begin{array}{l}\text { Bowel } \\
\text { obstruction } \\
23.3 \%\end{array}$ & $\begin{array}{l}\text { Abdominal trauma } \\
16.2 \%\end{array}$ & $\begin{array}{l}\text { Generalized acute } \\
\text { peritonitis } 27.9 \%\end{array}$ & $\begin{array}{l}\text { strangulated hernia } \\
19.5 \%\end{array}$ \\
\hline & $\begin{array}{l}\text { strangulated } \\
\text { hernia } \mathbf{2 2 . 2} \%\end{array}$ & $\begin{array}{l}\text { Abdominal } \\
\text { trauma } 7.8 \%\end{array}$ & $\begin{array}{l}\text { strangulated } \\
\text { hernia } 7 \cdot 5 \%\end{array}$ & $\begin{array}{l}\text { Acute } \\
\text { intussusception } \\
13.9 \%\end{array}$ & $\begin{array}{l}\text { Acute appendicitis } \\
13.8 \%\end{array}$ \\
\hline
\end{tabular}

\section{5) Strangled Parietal Hernias}

They are the second cause of digestive surgical emergencies in children with $19.5 \%$ of cases in our series. The strangulated inguinoscrotal hernia is the most common anatomical form (76.4\%). The literature recommends operating an inguinal hernia in children as soon as the diagnosis confirmed, even in the newborn before leaving maternity, because of the high risk of hernia strangulation, which is around 25 $\%$ [25]. The complication rate (strangulation episodes, testicular growth disorders) is $11 \%$ after strangulation compared to $0.6 \%$ in children operated on before any strangulation episode [26].

The umbilical hernia (UH) exceptionally strangles [27]; we observed only two cases during our study. For Merie et al. [28], the diameter of the collar is inversely proportional to the risk of strangulation, which constitutes, within the framework of $\mathrm{UH}$, a surgical emergency that cannot be postponed.

In our series, a small loop (the ileum) is the main herniated viscera and it was viable in 12 cases out of 16. The literature agrees that the hernia content is often small bowel [29,30]. N'gom et al. [31] in a study of strangulated inguinal hernias in children found the ileum in $76.3 \%$ of cases.

The corollary of hernia constriction is a gonadal and / or intestinal ischemia that can lead to necrosis, then to intestinal perforation. This was the case in 4 patients in our series who underwent intestinal resection with ileo-ileal anastomosis also observed in other series [29,31].

\section{6) Acute Intussusception}

Intestinal intussusception in children is an emergency to be recognized by any primary care physician. The risk of irreversible intestinal suffering leading to digestive perforation with or without septic shock is substantial if the pathology is not immediately recognized and if adequate management is not prompt [32]. It is one of the most frequent abdominal emergencies in infants. Three English studies report a frequency of 1.57 to 4 per 1000 births [33,34]. There is a clear predominance among boys (sex ratio: 2/1). In our study, it was idiopathic intestinal invagination in all cases. In fact, in the literature, it is more frequent with 90\% of cases [35] and the ileo-caecal-colic form is predominant as pointed out by Moore [35] with 84\% cases.

In our series, all the patients underwent manual reduction by laparotomy, because all the patients are admitted to the service after several days of progression of the disease and in poor general condition with suspicion of necrosis or intestinal perforation; which contraindicates treatment with a pneumatic or water-soluble enema. Whereas it is performed in $90 \%$ of cases before intestinal intussusception in Western countries where patients are often admitted early [32].

Abdominal trauma, with five cases including three 
Citation: Mboutol-Mandavo C, Détsélé RC, Miéret JC, Akobande NE, Ondima IPL, Odzébé AWS. Management of Digestive Surgical Emergencies in Children in a Developing Country (Newborns Excluded). Asp J Pediatrics Child Health. 2020 Feb 18;2(1):19-29.

\section{Original Article}

abdominal contusions and two cases of the abdominal wound, is the fifth cause of digestive surgical emergencies. Abdominal contusions in $73 \%$ of cases dominate for Mboutol-Mandavo et al. [36] in abdominal trauma, this rate is $98 \%$ of cases in Europe, the spleen is the most affected organ and conservative treatment is often recommended [37].

\section{Therapeutic Aspects:}

1) Time for Surgical Management

The majority of patients (86.3\%) were operated on after 12 hours after admission to the emergency room. This more or less long delay has also been reported by other authors in Africa [3,8]. In our series, it is attributable to a diagnostic doubt, to socio-economic problems and the dysfunction of our hospital structure (availability of the operating room, availability of the pediatric surgeon, and availability of the anesthetist-resuscitator). These results reflect the inadequacy of appropriate health infrastructure, the shortage of qualified health personnel and the virtual absence of a social security system in our country.

\section{2) Surgical Treatment}

Laparotomy was the only surgical approach practiced during our study, apart from herniotomies. Laparoscopy did not perform during our study due to the lack of logistical means specific to this type of surgery. It is a surgical technique whose use is booming in the treatment of surgical emergencies digestive for a few years in developed countries [38].

Appendectomy was the most commonly performed surgical procedure (58.7\%). These results are similar to those of Mabiala et al. [3] in Congo, Habou et al. [8] in Niger, where appendectomy with abdominal cleansing and drainage is the most commonly performed surgical procedure, due to the predominance of appendicular peritonitis found during our study.

\section{Evolutionary Aspects:}

1) Duration of Post-Operative Hospitalization

The average length of postoperative hospitalization was 9.8 days with extremes of 1 and 35 days. It is by the occurrence of postoperative complications.
However, there is a discrepancy with the results of the study by Tseng et al. [7] in Asia, which found $4.9 \pm$ 3.3 days this difference that can be explained by the early diagnosis and surgical management in their practice.

\section{2) Operating Suites}

They were complicated in $33.7 \%$ of the cases in our series. Post-operative complications are dominated by parietal suppuration (77.8\%) as already pointed out by African authors [3,8].

We noted an overall mortality rate of $7.1 \%$. The age group from 1 month to 5 years was the most concerned with four cases (4.6\%). Indeed, the age below 6 years constitutes an element increasing the morbidity and mortality of patients $[3,4,8]$. The causes of death in our series (septic shock, hypovolemic shock, multi-visceral failure) have been reported by other authors $[3,8]$.

There is a discrepancy with the results of the Tseng et al. [7] in Asia; this difference with the mortality rate found in the study by Tseng et al. [7] is due to the availability of diagnostic and therapeutic means not available in developing countries. The organization of perioperative management, the availability of more sophisticated diagnostic and therapeutic means could improve the prognosis of these emergencies in children.

\section{Conclusion}

Digestive surgical emergencies in children remain a concern for pediatric surgeons worldwide, particularly in sub-Saharan Africa. It represents a frequent nosological entity in our practice. Abdominal pain is the first reason for consultation. Appendicular peritonitis are the first cause of digestive surgical emergency in children in our practice. This is due to the delay in consultation often linked to financial problems, insufficient health infrastructure. It remains a worrying problem for pediatric surgeons in Africa.

\section{Conflict of interest}

The authors declare no conflict of interest. 
Citation: Mboutol-Mandavo C, Détsélé RC, Miéret JC, Akobande NE, Ondima IPL, Odzébé AWS. Management of Digestive Surgical Emergencies in Children in a Developing Country (Newborns Excluded). Asp J Pediatrics Child Health. 2020 Feb 18;2(1):19-29.

\section{Original Article}

\section{References}

[1] Goujard E. Visceral emergencies in pediatric anesthesia. MAPAR. 2000;105:15.

[2] Aubineau JV. Digestive emergencies in infants: anesthetic care. Prat Anesth Rean. 2007;11(5):347-51.

[3] Mabiala-Babela JR, Pandzou N, Koutaba E, GangaZandzou S, Senga P. Retrospective study of visceral surgical emergencies in children at the University Hospital Center of Brazzaville (Congo). Med Trop (Mars). 2006 Apr;66(2):172-76. [PMID: 16775942]

[4] Kassegne I, Kanassoua K, Sewa EV, Tchangaï B, Sambiani J, Ayité AE, Dosseh ED. Management of surgical abdominal emergencies in Kara teaching hospital (Togo): 10-year retrospective study of 594 cases. Med Sante Trop. 2015 Jan-Mar;25(1):39-43. [PMID: 25295481]

[5] Lansky SB, List MA, Lansky LL, Ritter-Sterr C, Miller DR. The measurement of performance in childhood cancer patients. Cancer. 1987 Oct 1;6o(7):1651-56. [PMID: 3621134]

[6] Score WHO. Available on

http://www.antalvite.fr/pdf/SCORE\%2oOMS.pdf.

Accessed December 12, 2019.

[7] Tseng YC, Lee MS, Chang YJ, Wu HP. Acute abdomen in pediatric patients admitted to the pediatric emergency department. Pediatrics \& Neonatology. 2008 Aug 1;49(4):126-34.

[8] Habou O, Adamou H, Amadou MM, Magagi A, Adamou M, Halidou M, Ganiou K. Digestive surgical emergencies in children at Zinder National Hospital (Niger): epidemiological, etiological and prognostic aspects about 283 cases. Annals of Abdou Moumouni University 2015;2:36-42.

[9] Binam F, Takongmo S, Kingue S, Mbanya D, Njip JM, Hagbe P. Emergency care circuit in a hospital in the city of Yaoundé. J Europ Urg. 2001;14(4):233-9.

[10] Abantanga FA, Nimako B, Amoah M. The range of abdominal surgical emergencies in children older than 1 year at the Komfo Anokye Teaching Hospital, Kumasi, Ghana. Ann Afr Med. 2009 Oct-Dec;8(4):23642. [PMID: 20139546]

[11] Adejuyigbe O, Fashakin EO. Acute intestinal obstruction in Nigerian children. Trop Gastroenterol. 1989 Jan-Mar;10(1):33-40. [PMID: 2718254]

[12] Republic of the Congo - National Human Development Report 2016. Brazzaville: United Nations Development Program, 2016.
[13] Smith J, Fox SM. Pediatric Abdominal Pain: An Emergency Medicine Perspective. Emerg Med Clin North Am. 2016 May;34(2):341-61. [PMID: 27133248] [14] Hijaz NM, Friesen CA. Managing acute abdominal pain in pediatric patients: current perspectives. Pediatric Health Med Ther. 2017 Jun 29;8:83-91. [PMID: 29388612]

[15] McCollough M, Sharieff GQ. Abdominal surgical emergencies in infants and young children. Emergency Medicine Clinics. 2003 Nov 1;21(4):90935.

[16] Rothrock SG, Green SM, Hummel CB. Plain abdominal radiography in the detection of major disease in children: a prospective analysis. Ann Emerg Med. 1992 Dec;21(12):1423-29. [PMID: 1443835]

[17] Kouamé N, Dieth AG1, Soumma A, Manewa FS, Ngoan-Domoua A, Ngbesso R. Management of acute non-traumatic abdominal pain in children in Abidjan: is the standard $\mathrm{x}$-ray/ultrasound combination still relevant? J Afr Imag Méd. 2017;9(1):17-20.

[18] Vasavada P. Ultrasound evaluation of acute abdominal emergencies in infants and children. Radiologic Clinics. 2004 Mar 1;42(2):445-56.

[19] Carty HM. Paediatric emergencies: non-traumatic abdominal emergencies. Eur Radiol. 2002 Dec;12(12):2835-48. [PMID: 12439562]

[20] van den Ende ED, Boellaard WP, Allema JH, Holscher HC, Putter H, Breslau PJ. Diagnostic surplus value of echography in children with acute abdominal pain. Ned Tijdschr Geneeskd. 2003 Jun 14;147(24):1174-77. [PMID: 12845838]

[21] Carrico CW, Fenton LZ, Taylor GA, DiFiore JW, Soprano JV. Impact of sonography on the diagnosis and treatment of acute lower abdominal pain in children and young adults. AJR Am J Roentgenol. 1999 Feb;172(2):513-16. [PMID: 9930815]

[22] Lowe LH, Penney MW, Stein SM, Heller RM, Neblett WW, Shyr Y, Hernanz-Schulman M. Unenhanced limited $\mathrm{CT}$ of the abdomen in the diagnosis of appendicitis in children: comparison with sonography. American Journal of Roentgenology. 2001 Jan;176(1):31-35.

[23] Kaiser S, Frenckner B, Jorulf HK. Suspected appendicitis in children: US and CT-a prospective randomized study. Radiology. 2002 Jun;223(3):63338.

[24] Adamou H, Amadou MMI, Habou O, Adamou M, 
Citation: Mboutol-Mandavo C, Détsélé RC, Miéret JC, Akobande NE, Ondima IPL, Odzébé AWS. Management of Digestive Surgical Emergencies in Children in a Developing Country (Newborns Excluded). Asp J Pediatrics Child Health. 2020 Feb 18;2(1):19-29.

\section{Original Article}

Magagi A, Elh Adakal O and al. Delayed diagnosis and prognostic implication in the African environment. Digestive surgery emergencies at Zinder national hospital, Niger. European Scientific Journal. 2015;11(12):251-62.

[25] Galinier P, Bouali O, Juricic M, Smail N. Inguinal hernia in children: practical update. Arch Pédiatr. 2007;14(4):399-403.

[26] Stephens BJ, Rice WT, Koucky CJ, Gruenberg JC. Optimal timing of elective indirect inguinal hernia repair in healthy children: clinical considerations for improved outcome. World J Surg. 1992 SepOct;16(5):952-56. [PMID: 1462636]

[27] Papagrigoriadis S, Browse DJ, Howard ER. Incarceration of umbilical hernias in children: a rare but important complication. Pediatr Surg Int. 1998 Dec;14(3):231-32. [PMID: 9880759]

[28] Merie JM. Umbilical repair in children. Pediatr Surg Int. 2006;22:446-48.

[29] Ngom G, Fall M, Alumeti MD, Ndour O, Fall I, Ndoye M. Strangulated inguinal hernias of children in African environments: about 135 cases. Rev Trop Chir. 2009;3:13-16.

[30] Ameh EA. Incarcerated and strangulated inguinal hernias in children in Zaria, Nigeria. East African medical journal. 1999 Sep;76(9):499-501.

[31] Bamigbola KT, Nasir AA, Abdur-Rahman LO, Adeniran JO. Complicated childhood inguinal hernias in UITH, Ilorin. Afr J Paediatr Surg. 2012 SepDec;9(3):227-30. [PMID: 23250245]

[32] Vandertuin L, Vunda A, Gehri M, Sanchez O, Hanquinet S, Gervaix A. Intestinal intussusception in children: truly a classic triad? Rev Med Suisse. 2011 Feb 23;7(283):451-55. [PMID: 21452514]

[33] Macmahon B. Data on the etiology of acute intussusception in childhood. Am J Hum Genet. 1955 Dec;7(4):430-38. [PMID: 13275464]

[34] Court D, Knox G. Incidence of intussusception in Newcastle children. $\mathrm{Br}$ Med J. 1959 Sep 12;2(5149):408-9. [PMID: 13812385]

[35] Moore SW, Kirsten M, Müller EW, Numanoglu A, Chitnis M, Le Grange E, Banieghbal B, Hadley GP. Retrospective surveillance of intussusception in South Africa, 1998-2003. J Infect Dis. 2010 Sep 1;202 Suppl:S156-61. [PMID: 20684696]

[36] Mboutol-Mandavo C, Mabiala-Babela JR, Miéret
JC, Koutaba E, Ondima IPL. Abdominal trauma in children about 37 cases at the Brazzaville University Hospital. Rev Afr Chir Spéc. 2015;9(3):11-17.

[37] Meyer P, Baugnon T, Rousseau V. Child's abdominal trauma. EMC- Pédiatrics. 2007; 4:15-19.

[38] D'Agostino J. Common abdominal emergencies in children. Emerg Med Clin North Am. 2002 Feb;20(1):139-53. [PMID: 11826631] 